\title{
Colombia's Progress: Internal Peace and Foreign Trade
}

\author{
Andrew F. Johnson \\ Texas A\&M University-Corpus Christi \\ Rusty V. Karst
Texas A\&M University-Corpus Christi
}

The nation of Colombia has made great progress in securing internal peace through an agreement with the Revolutionary Armed Forces of Colombia (FARC) and policing of drug cartels. These important steps have contributed to increased international commerce based on strong trade agreements and a more global outlook than many other Latin American nations have embraced. Colombia stands poised for additional growth; however, the challenges of internal development and wide-spread corruption remain.

Keywords: Colombia, Revolutionary Armed Forces of Colombia (FARC), economic development

\section{INTRODUCTION}

Like most other countries in Latin America, Colombia has at times experienced violence, political upheaval, corruption, and high rates of poverty. However, Colombia has made great progress in promoting global trade, increasing domestic tranquility, raising living standards, and attracting foreign investment. Additionally, the nation has created an environment favorable to trade and has secured foreign trade relationships with Latin American and global partners. This article discusses the successes and challenges of Colombia in the context for conducting business in the nation.

\section{INTERNAL PEACE}

Colombia has worked to combat powerful drug cartels and settle domestic conflicts. While at times even an extreme example, the nation is not an exception among Latin America in terms of security concerns. The country has reduced crime and the influence of drug cartels. As one indicator of the increased level of safety within the country, kidnappings have decreased 93\% from 1995 to 2015 (Department of State, 2017). More recently, increases in domestic tranquility can be attributed to a peace accord with the longest running insurgency group in the world (WIPO, 2019; Karl, 2017). Signing of the peace accord is one of the most significant events in the nation's recent history as proponents of the agreement hail it as a turning point for the nation's development and future prosperity.

\section{The Peace Accord: Final Agreement}

In November 2016, a complex peace accord was concluded between the government of Colombia and the Marxist revolutionary group known as Fuerzas Armadas Revolucionarias de Colombia (FARC) 
(translation: Revolutionary Armed Forces of Colombia). The accord formally ended one of the most extensive contemporary conflicts in the Western Hemisphere (Final Agreement, 2016; Karl, 2017). The conflict claimed the lives of an estimated 218,000 people ( $80 \%$ of victims were civilians) with millions more displaced. It is estimated that one million victims of violence related to the conflict live in Colombia while many others fled to live abroad (Final Agreement, 2016; Faiola, 2017). Partly as a result of the massive influx of people into cities, the urban population is now $81.1 \%$ of the 48.1 million inhabitants of Colombia (CIA, 2020).

Formed to advocate a leftist political ideology, FARC used criminal activity to provide funding for their cause. The group was a major contributor to the illegal narcotics trade as well as other criminal activity most notably kidnapping for ransom. At its pinnacle, FARC controlled an estimated $40 \%$ of the country's territory, mostly in the sparsely populated and heavily forested northern and eastern regions (Karl, 2017).

As a condition of the peace accord, over 12,000 revolutionary fighters gave up their arms to join the mainstream population. While approximately 1,000-1,200 militants refused to surrender and joined smaller bands of revolutionary groups instead (Cobb, 2018).

The peace accord provides for representation in the political process for the FARC's political ideology through establishment of a formal political party (Faiola, 2017). The party is guaranteed seats in the national legislature for a set period and can field candidates in subsequent elections. Further, former revolutionaries were provided with direct payments of about \$200 USD per month for two years as they transition into mainstream society following a pledge to not commit further criminal activity and surrender weapons (Faiola, 2017). The peace accord emphasized providing truth and closure along with some monetary compensation for victims. Jail sentences for former revolutionaries were suspended in favor of "effective liberty restrictions" of up to eight years including for those who confessed to war crimes (Final Agreement, 2016; Casey, 2016).

During six decades of conflict, millions of Colombians fled abroad and moved to urban centers in hopes of escaping the violence which was extensive in rural areas. Since 1985, security issues and conflict have displaced an estimated 5.7 million (IDMB/NRC, 2015). As of 2015, Colombia had the second largest internally displaced population in the World (IDMB/NRC, 2015). Bogota and Medellin have experienced the largest numerical growth due to in-country migration swelling from populations of 4.3 million and 2.22 million in 2005 (Library of Congress, 2007) to 10.78 million and 3.97 million in 2019, respectively (CIA, 2019).

Passage of the peace accord facilitated the need to resettle several thousand revolutionaries, many of whom were destined for neighborhoods with the same poor conditions. While only representing a fraction of the migrant population within the country, the former revolutionaries represent a highly vulnerable population. The failure of this group to adequately assimilate may lead to increased crime or even the resumption of militant activities (Kaplan \& Nussio, 2018). Accordingly, social services are an important aspect of this process.

Maintaining security is crucial for lowering recidivism rates among former revolutionaries (Kaplan \& Nussio, 2018) however, that is only one aspect. The peace accords specifically addressed the need to provide social development in health, education, and poverty eradication (Final Agreement, 2016, p. 2633). Many of the former revolutionaries only have training in warfare since joining FARC in their teens and thus have received little formal education. Due to the recruitment of many fighters at a young age, literacy rates among this population are estimated at 30\% (Calderon, 2016). As such, providing educational opportunities are paramount to ensure that former revolutionaries can assimilate into society and find work.

A continued peace is important for the future of Colombia for many reasons including to foster a favorable environment for trade. The country's economy has strengthened greatly since the 1990's and with assurances for greater domestic tranquility, foreign investment has continued to increase (World Economic Forum, 2018; Long, 2019). 


\section{FOREIGN TRADE}

Colombia is situated in a strategic location at the crossroads between Central and South America. It is the only South American nation with access to both the Pacific and Atlantic Oceans (CIA, 2020). The Bureau of Economic and Business Affairs of the U.S. Department of State both note Colombia "has a comprehensive legal framework for business and foreign direct investment" (2017). Further, Colombia is a member of the Pacific Alliance trade bloc with Peru, Chile, and Mexico. These nations collectively represent a market of over 200 million people and the four alliance members rank among the strongest economies in Latin America (Flannery, 2016).

Colombia's location makes it an important hub and facilitates logistics for oil shipment and direct flights of fresh flowers to the U.S. market via a 3.5-hour flight to Miami (McQuaid, 2011). Most of the nation's export production comes from goods such as coal, gold, oil, coffee, cut flowers, emeralds, and agricultural products. The top destinations for exports are the U.S. (28.5\%), Panama $(8.6 \%)$ and China (5.1\%) (CIA, 2020). Due to the heavy dependence on commodity exports, global price fluctuations, particularly the price of crude oil, can have a profound impact on the economy (CIA, 2020).

Colombia's median age is 30.4 years and the national literacy rate stands at 94.7\% (CIA 2020). An estimated $28 \%$ of the populated was living below the poverty rate in 2017 which remained nearly unchanged from $28.8 \%$ in 2000. The 2017 unemployment rate was $9.3 \%$ (CIA 2020). The Colombian minimum wage is equivalent to about \$260 (USD) per month, below average for the region (Bernal, 2019) while the per capita Gross National Income (GNI) is estimated at $\$ 6,180$ (USD) (The World Bank, 2018). The market of almost 50 million people is about the size of South Korea while the 2018 GDP of $\$ 352$ million is comparable to Denmark (United Nations, 2020). Many educated young people live in the urban areas due to the government's relatively large investment in schools, universities, and job training programs (CIA, 2020). For instance, a business tax supports The National Learning Service (Servicio Nacional de Aprendizaje) (SENA) to provide career training at no direct cost to students (SENA, 2018).

Colombia has an important trade partnership with the United States underpinned by the United States Colombia Trade Promotion Agreement (FTA), signed in May 2012 (U.S. Department of State, 2017). In 2018, Colombia joined the Organization for Economic Cooperation and Development (OECD) and was the first Latin American country to join the North Atlantic Treaty Organization (NATO) as a global partner alongside other countries such as Australia, Japan, New Zealand, Pakistan, and South Korea (Murphy, 2018). Colombia has formal trade agreements with El Salvador, Guatemala, Honduras, Costa Rica, Panama, Israel, Chile, South Korea, the European Free Trade Association (EFTA) countries, and the European Union (International Trade Administration, 2020).

Current data suggest there is a generally positive growth trend for the Colombian economy (Long, 2019). However, the nation has experienced sharp swings in some economic indicators as for Inward Foreign Direct Investment (IFDI). As noted by the United Nations Conference on Trade and Development annual FDI inflows decreased over 20\% in the year 2018. This decrease was the highest annual decrease for any nation in South America. Root causes of this swing are due to sharp reductions in manufacturing and energy sector investment (UNCTAD, 2018). During this same time period, Outward Foreign Direct Investment (OFDI) increased (UNCTAD, 2018).

\section{MOVING FORWARD: CHALLENGES AHEAD}

While the rapid emergence of Colombia as a leader among Latin American countries is impressive, several significant issues remain. Both logistical and social cohesion are challenging due to poor access to parts of the nation due to the mountainous topography and dense forestation in eastern portions of the country (Bushnell, 1993; Valencia, 2016). Security concerns remain as the stability brought about through the peace accords is not deep-rooted (Norma, 2017; Faiola, 2018). These factors make the movement of goods and people across various regions of the nation more challenging. However, even as Colombia is experiencing significant economic gains and the level of domestic security has greatly improved, there 
remain significant challenges. In this section, the evolving concerns over security, development challenges, and wide-spread corruption are discussed.

\section{Security}

Even with the peace accord in place, domestic terrorism remains a concern for Colombia as other smaller revolutionary groups have not yet formalized peace agreements with the government (Faiola, 2018). A notable example occurred in 2017 when an urban terrorist group killed three and injured nine people at a Bogota mall in 2017 by setting off a bomb (Chavez, 2017). The illegal drug trade remains a concern within the country. Following the breakup of the major cartels, most notably the Medellin Cartel, smaller criminal enterprises continued to engage in illegal narcotics production and trafficking (Norman, 2017). The continued presence of the drug trade perpetuates some violence within the nation even as levels are significantly lower than the times when significant portions of the nation was under the control of a major cartel. As these issues which could potentially destabilize the country remain it is paramount that they are addressed if Colombia is to continue its economic growth and social progress.

\section{Development}

In 2014, the United Nations estimated that $13 \%$ of the urban population of Colombia lived in informal neighborhoods or slums. While this is a vast improvement from an estimate of $31 \%$ in 1990 (United Nations, 2018), this figure indicates there are millions of Colombians who reside in substandard dwellings in communities that lack basic services. Housing remains one of the challenges to increasing quality of life for Colombians.

Urban populations across Central and South America have dramatically increased as cities represent more educational opportunity, safety, and jobs than rural areas (Mahabir, et al., 2016; Samad et al., 2012). More recently, instability in Venezuela has driven an estimated 1.4 million to seek refuge in Colombia (Cobb, 2019).

However, many in-country immigrants to cities are not able to realize the supposed benefits of cities due in large part to the living conditions. As mass migration to cities has occurred, many have settled in informal (or illegal) neighborhoods (for a discussion on illegal settlements see: Gill-Chin, 1987). These neighborhoods are often on the hillsides surrounding the nation's largest cities and lack the most basic services such as paved roads, electricity, sewer, sanitation, and clean water (Ospina, 1985). The lack of streetlights threatens the safety of residents at night. The isolation due to geographic location and limited access to public transportation led to increased crime and little access to security, education, or healthcare (UN-Habitat, 2003).

Home ownership in the United States, Canada, and European nations is much different than it is in Latin America as it is not necessarily tied to a higher income or economic status. People living at the lower socio-economic levels in Latin America are much less likely to rent a home. Instead incremental housing (self-built) is a common method for obtaining shelter among the poor. The nation's very poor and very wealthy are more likely to own a house while middle class households are more likely to rent. Even still, Colombia has the highest percentage of households who rent their homes in Latin American at 39.1\% (Blanco, et al., 2016). Among the richest $10 \%$ and poorest $10 \%$ of people in Colombia, roughly $60 \%$ own their home with lower figures for ownership among the remaining $80 \%$ of the population that fall between these two extremes. Some developments, such as Ciudad Verde, south of Bogota supplies affordable housing for sale to the lower middle classes. However, these types of developments are revolutionary and draw a sharp contrast to incremental housing (Johnson \& Karst, 2020). For the poorest segments of the population, home "ownership" almost always equates to self-help or illegal housing (Blanco, et al., 2016).

\section{Corruption}

Related to the challenges for internal development is the underlying issue of corruption. The U.S. Department of State and the World Economic Forum note that corruption is one of the greatest challenges to doing business in Colombia (U.S. Department of State, 2017; World Economic Forum, 2018). As the urban population has swelled, critical large infrastructure projects have been hampered by corruption (Diaz, 
2017). This has led to transportation and other infrastructure deficits contributing to the overall poor state of public infrastructure (World Economic Forum, 2018). Corruption and political infighting occur at virtually all levels of government (Diaz, 2017; Transparency International, 2017).

Corruption in Latin America may have a diminishing effect on trade however exchange relationships involving corruption are not this straightforward (de Jong \& Bogmans, 2011; Thede \& Gustafson, 2012). Level of corruption does have an effect on which partners may be willing to trade (Belgibayeva \& Plekhanov, 2019). Literature suggests that successful trading partners are those that are more familiar with and able to navigate a corrupt environment. (de Jong \& Bogmans, 2011; Thede \& Gustafson, 2012). Any changes in the level of corruption would suggest the need for trade partners to adapt their practices. While corruption may call for agility on the part of trade partners, it often does not lead to favorable in-country outcomes as with the case of infrastructure development.

\section{CONCLUSION}

Colombia has faced tremendous challenges and is now situated among the most promising economies in Latin America. The relatively swift transformation of the nation from one of near perpetual internal combat to a much safer nation engaged in the global community is noteworthy. This article has discussed one of the anchors of this transformation in the peace accord. The nation of Colombia must face significant ongoing challenges as it continues to progress.

\section{REFERENCES}

Belgibayeva, A., \& Plekhanov, A. (2019). Does corruption matter for sources of foreign direct investment? Review of World Economics, 155(3), 487-510.

Bernal, P. (2019). Colombia's 'disastrous' minimum wage is restraining its development. Latin American Post. Retrieved from https://latinamericanpost.com/28734-colombias-disastrous-minimum-wageis-restraining-its-development

Blanco, A., Gilbert, A., \& Kim, J. (2016). Housing tenure in Latin American cities: The role of household income. Habitat International, 51, 1-10.

Bushnell, D. (1993). The making of Colombia: A nation in spite of itself. Los Angeles, CA: University of California Press.

Calderon, J. (2016). FARC rebel rehab hopes to create lasting peace in Colombia. Newsweek. Retrieved from http://www.newsweek.com/farc-rebel-rehab-hopes-create-lasting-peace-colombia-451620

Casey, N. (2016). Colombia's Congress approves peace accord with FARC. The New York Times. Retrieved from https://www.nytimes.com/2016/11/30/world/americas/colombia-farc-accord-juanmanuel-santos.html

Central Intelligence Agency (CIA). (2018). The world factbook. Washington, DC: Central Intelligence Agency. Retrieved from https://www.cia.gov/library/publications/the-worldfactbook/geos/co.html

Chavez, N. (2017). Police arrest 8 in deadly Colombia mall explosion. CNN. Retrieved from https:/www.cnn.com/2017/06/25/americas/colombia-mall-explosion-arrests/index.html

Cobb, J.S. (2018). Colombia FARC rebel dissidents number 1,200, military says. Reuters. Retrieved from https://www.reuters.com/article/us-colombia-peace-dissidents/colombia-farc-rebel-dissidentsnumber-1200-military-says-idUSKBN1GW2LF

Cobb, J.S. (2019). Colombia laments lack of aid for growing Venezuela migration crisis. Reuters. Retrieved from https://www.reuters.com/article/us-venezuela-politics-colombia/colombialaments-lack-of-aid-for-growing-venezuela-migration-crisis-idUSKCN1VA28D

Colombia. (2018). Global competitiveness index. World Economic Forum. Retrieved from http://reports.weforum.org/global-competitiveness-index-2017-2018/countryeconomyprofiles/\#economy $=\mathrm{COL}$ 
Corruption Perceptions Index. (2017). Transparency International. Retrieved from https://www.transparency.org/news/feature/corruption_perceptions_index_2017

de Jong, E., \& Bogmans, C. (2011). Does corruption discourage international trade? European Journal of Political Economy, 27(2), 385-398.

Diaz, F.A. (2017). Colombians are fed up with government corruption. U.S. News. Retrieved from https://www.usnews.com/news/best-countries/articles/2017-04-17/in-colombia-the-public-outcryover-corruption-grows

Faiola, A. (2017). Colombia's FARC rebels launch a political party, trading bullets for blazers. The Washington Post. Retrieved from http://wapo.st/2wucExf?tid=ss mail\&utm term $=.3 \mathrm{c} 788 \mathrm{~b} 362910$

Faiola, A. (2018). Two years after Colombia's peace accord, the historic pact is in jeopardy. The Washington Post. Retrieved from https://wapo.st/2leioGx?tid=ss_mail\&utm term=.7cba4b801255

Final agreement to end the armed conflict and build a stable and lasting peace. (2016). Republic of Colombia; Fuerzas Armadas Revolucionarias de Colombia. Retrieved from http://especiales.presidencia.gov.co/Documents/20170620-dejacion-armas/acuerdos/acuerdofinal-ingles.pdf

Flannery, N.P. (2016). What should investors know about Latin America's Pacific Alliance? Forbes. Retrieved from https://www.forbes.com/sites/nathanielparishflannery/2016/05/30/what-shouldinvestors-know-about-latin-americas-pacific-alliance/\#77e3e3e04292

Gill-Chin, L. (1987). Housing policies for the urban poor in developing countries. Journal of the American Planning Association, 53(2), 176-185.

Gutierrez, D. (2016). The coming of los buendí: Colombia's peace process and the difficulty that lies ahead. Harvard International Review, 37(3), 4-6.

Internal Displacement Monitoring Centre/ Norwegian Refugee Council (IDMC/NRC). (2014). Colombia: Displacement continues despite hopes for peace. Geneva.

International Trade Administration. (2020). Colombia - Trade Agreements. U.S. Department of Commerce. Retrieved from https://www.export.gov/article?id=Colombia-Trade-Agreements

Investment Climate Statements. (2017). United States Department of State. Washington, D.C.: Bureau of Economic and Business Affairs. Retrieved from https://www.state.gov/e/eb/rls/othr/ics/2017/wha/270056.htm

Johnson, A.F., \& Karst, R.V. (2020). Ciudad Verde: A new neighborhood for Colombia. The International Trade Journal, 34(1), 151-161.

Kaplan, O., \& Nussio, E. (2018). Explaining recidivism of ex-combatants in Colombia. Journal of Conflict Resolution, 62(1), 64-93.

Karl, R.A. (2017). Forgotten peace: Reform, violence, and the making of contemporary Colombia (Vol. 3). University of California Press, Oakland, CA.

Library of Congress. (2007). Country profile: Colombia. Retrieved from https://www.loc.gov/rr/frd/cs/profiles/Colombia-new.pdf

Long, G. (2019). Colombia bucks dismal trend for Latin American economies. Financial Times. Retrieved from https://www.ft.com/content/d4f47704-008d-11 ea-b7bc-f3fa4e77dd47

Mahabir, R., Crooks A., Croitoru, A., \& Agouris, P. (2016). The study of slums as social and physical constructs: Challenges and emerging research opportunities. Regional Studies, Regional Science, 3(1), 399-419.

McQuaid, J. (2011). Chances are the bouquet you're about to buy came from Colombia. What's behind the blooms? Smithsonian Magazine. Retrieved from https://www.smithsonianmag.com/travel/thesecrets-behind-your-flowers-53128/

Murphy, H. (2018). Colombia to be NATO's first Latin American global partner. Reuters. Retrieved from https://www.reuters.com/article/us-colombia-nato/colombia-to-be-natos-first-latin-americanglobal-partner-idUSKCN1IR0E8 
Norman, S.V. (2018). Narcotization as security dilemma: The FARC and drug trade in Colombia. Studies in Conflict \& Terrorism, 41(8), 638-659.

Ospina, J. (1985). Self-help housing and social change in Colombia. Community Development Journal, 20(4), 257-266

Republic of Colombia. (2016). Summary of Colombia's agreement to end conflict and build peace.

Presidencia de la República. Retrieved from

http://www.altocomisionadoparalapaz.gov.co/herramientas/Documents/summary-of-colombiaspeace-agreement.pdf

Servicio Nacional de Aprendizaje (SENA). (2018). Retrieved from http://www.sena.edu.co

Taylor, L. (2018). The Odebrecht corruption scandal is already shaking up Colombia's presidential vote. World Politics Review. Retrieved from https:/www.worldpoliticsreview.com/articles/23897/theodebrecht-corruption-scandal-is-already-shaking-up-colombia-s-presidential-vote

The World Bank. (2018). Doing business 2018. Retrieved from http://www.doingbusiness.org/ /media/WBG/DoingBusiness/Documents/AnnualReports/English/DB2018-Full-Report.pdf

The World Bank. (2020). World Development Indicators. Retrieved from https://datacatalog.worldbank.org/dataset/world-development-indicators

Thede, S., \& Gustafson, N.Å. (2012). The multifaceted impact of corruption on international trade. The World Economy, 35(5), 651-666.

UN-Habitat. (2003). The challenge of slums - Global report on human settlements 2003. London: United Nations Human Settlements Programme.

United Nations Conference on Trade and Development (UNCTD). (2019). World investment report 2019. Retrieved from https://unctad.org/en/PublicationsLibrary/wir2019_en.pdf

United Nations. (2018). Millennium development goals indicators. United Nations Statistics Division. Retrieved from http://mdgs.un.org/unsd/mdg/default.aspx

Valencia, S. (2016) Caught Between Spaces: Socio-Environmental Vulnerability in Formal and Informal Peri-Urban Bogotá and Soacha, Colombia. Lund, Sweden: Lund University. 